\title{
Can thin-billed prions Pachyptila belcheri breed successfully on an island with introduced rats, mice and cats? The case of New Island, Falkland Islands
}

\author{
P. Catry $\cdot$ M. C. Silva $\cdot$ S. MacKay $\cdot$ A. Campos • \\ J. Masello $\cdot$ P. Quillfeldt $\cdot$ I. J. Strange
}

Received: 23 May 2006 / Revised: 17 August 2006 / Accepted: 22 August 2006 / Published online: 28 September 2006

(C) Springer-Verlag 2006

\begin{abstract}
Small burrowing petrels nesting on islands rarely survive introductions of mammalian predators. On New Island, a population of around two million pairs of thin-billed prions nests despite the presence of introduced ship rats, house mice and feral cats. Understanding the mechanisms of such coexistence is important, as it is important to establish a baseline for future monitoring. To do this, prion breeding success was determined for 7 years and in several habitats. Breeding success was high, except for the small fraction of the population that nests in tussock Poa flabellata stands, where several lines of evidence suggest signifi-
\end{abstract}

P. Catry $(\square)$

Instituto Superior de Psicologia Aplicada,

Unidade de Investigação em Eco-Etologia,

Rua Jardim do Tabaco 44, Lisboa 1149-041, Portugal

e-mail: paulo.catry@netc.pt

P. Catry · S. MacKay · A. Campos · J. Masello ·

P. Quillfeldt · I. J. Strange

New Island South Conservation Trust,

New Island, Falklands

M. C. Silva

Department of Biology,

University of Washington, Seattle,

WA 98195, USA

M. C. Silva

Departamento Biologia Animal,

Faculdade Ciências, Universidade de Lisboa,

Ed. C2-3piso, Lisboa 1749-016, Portugal

J. Masello · P. Quillfeldt

Max-Planck Institute for Ornithology,

Vogelwarte Radolfzell, Schlossallee 2,

Radolfzell 78315, Germany cant predation by rats. Such high breeding success possibly resulted from predator swamping in this highly seasonal environment. This study suggests that introduced mammals do not currently depress thin-billed prion breeding success on New Island. However, cats and rodents might have future harmful effects if external factors depressed the prion population or allow a significant population growth of predators on New Island.

\section{Introduction}

Mammal introductions to oceanic islands have been identified as one of the major causes of local and global extinctions of bird species in historical times (Newton 1998). Small burrow-nesting seabirds are particularly vulnerable, as they lack basic anti-predatory adaptations and are easily subdued by small mammals, such as rats and even mice (e.g. Moors and Atkinson 1984; Cuthbert and Hilton 2004). Most of the islands where rats have been introduced have completely lost their small burrowing petrel avifauna (e.g. Martin et al. 2000). New Island, in West Falklands, South Atlantic, harbours what is probably one of the largest small petrel colonies in the world, with an estimated two million pairs of thin-billed prions Pachyptila belcheri (Catry et al. 2003). Ship rats Rattus rattus, house mice Mus musculus and cats Felis catus have possibly been present on the island for at least 100 years and yet prions have been able to persist in their presence. However, it is not known how this coexistence is maintained. Given that ecosystem changes might influence populations of both predator and prey, affecting any present-day equilibrium, and because thin-billed prions 
are known to breed only at four archipelagos (Brooke 2004), with the population from New Island possibly representing almost $30 \%$ of the species world population (Catry et al. 2003; Brooke 2004), it is important to get a better understanding and monitor this situation. Furthermore, a better understanding of this system might help clarifying the impact of predators in other islands and the reasons for inter-island variability. The managers of New Island also need information on the impact of predators, to assess present and future needs of would-be eradication projects. In this paper, we present estimates of breeding success of thin-billed prions over 7 years and in different habitats and show that, at present, prions can maintain a high breeding output despite the presence of predators that, elsewhere, have driven seabird prey to extinction.

\section{Methods}

New Island $\left(61^{\circ} 18^{\prime} \mathrm{W}, 51^{\circ} 43^{\prime} \mathrm{S}\right)$ covers an area of approximately 1,970 ha. Thin-billed prions nest in a wide variety of habitats (Catry et al. 2003), but the majority of the population can be found in lowland areas with deep soils, bare or covered with grasses and sorrel Rumex acetosella and on relatively steep slopes on upland areas, usually covered with short grass or feldmark-type vegetation and with scattered rocks. Currently, tussock stands cover a small percentage of New Island, but this habitat was included in the study because ongoing research indicates it is favoured by rodents.

To measure breeding success, we visited nests shortly after egg laying and immediately before fledging (see Strange 1980; Quillfeldt et al. 2003, 2006 for further information on the nesting cycle on New Island). Only nests where an egg was seen early in the season were included. Nests were inspected using different methodologies. On tussock areas, many nests are rather shallow, and from 1998-99 to 2000-01, nest contents were inspected by reaching into the burrows. In 2005-2006 we used a burrowscope to inspect all nests in tussock and upland areas. In deep lowland soils, most nest chambers cannot be reached, not even with the help of a burrowscope. In those areas, a hole was excavated above or near the nest chamber and covered with a removable slab of rock, allowing an easy inspection of the nest contents.

Data from lowland areas come from three distinct study plots in 1999-2000 and 2000-2001 and from two study plots in the remaining years. Data from the uplands come from four distinct study plots. Data from the tussock area is from one single study plot, except in
2005-2006, when three study plots were included. Study plots (which covered ca. 0.5 ha each) were widely separated (inter-plot distance generally being 500-1,000 m) to get a more representative estimate of breeding success in each habitat. In any 1 year, study plots within each major habitat type had no significant differences in values of breeding success and so results were pooled.

In 2000-2001, intensive rodent trapping took place around and inside the study plot in the tussock area. Traps were operated from 30 December to 28 February, thus starting a few days before hatching and continuing almost until fledging. A total of 14 traps were placed at 5-10 $\mathrm{m}$ intervals, surrounding the study plot. A further six traps were located close to prion burrows that had been predated the previous year. Captured rats were dissected to investigate stomach contents.

\section{Results}

Excluding tussock areas, breeding success of thinbilled prions, sampled in 7 years and in a range of habitats and study plots, was consistently high (Table 1), except in 2002-2003, when oceanographic conditions resulted in widespread breeding failures of many seabirds in West Falkland (e.g. Huin 2003, own unpublished data). Breeding success in tussock displayed a high annual variation. In 2 out of 4 years, it was significantly lower than in other habitats, dropping below $10 \%$ in the worst year (Table 1). Breeding success in tussock attained its higher level, both in absolute terms and relative to other areas, in the year when intensive rodent control took place (Table 1 ).

Nine $(60 \%)$ out of 15 rats trapped in 2000-2001 contained bird remains (down, feathers, flesh or blood clots) in their stomachs. Those rats were trapped near prion burrows and it is highly likely that most, if not all the remains, were from prion chicks. We observed, on several instances, chicks wounded from apparent rat bites and partly eaten prion chick corpses inside burrows.

\section{Discussion}

There are relatively few data on prion Pachyptila spp. breeding success anywhere in the world, but the available information suggests that thin-billed prion breeding success on New Island is generally high when compared to other small burrowing petrels, and broadly at the same level as in a thin-billed prion colony in the 
Table 1 Thin-billed prion breeding success (\% of eggs laid resulting in chick reaching fledging age) on different habitats and years on New Island, Falkland Islands

\begin{tabular}{|c|c|c|c|c|}
\hline Year & Tussock & Lowland & Upland & Statistical comparison \\
\hline 1998-1999 & $57.5(n=33)$ & $58.6(n=70)$ & & NS \\
\hline 1999-2000 & $45.0(n=40)$ & $71.5(n=123)$ & & $\begin{array}{l}\text { Fisher's exact test, } \\
P=0.004\end{array}$ \\
\hline 2000-2001 & $79.5^{\mathrm{a}}(n=39)$ & $67.1(n=234)$ & & NS \\
\hline $2002-2003$ & & $38.6^{\mathrm{b}}(n=70)$ & & \\
\hline 2003-2004 & & $70.1(n=77)$ & & \\
\hline 2004-2005 & & $82.5(n=80)$ & & \\
\hline 2005-2006 & $9.2(n=65)$ & $49.3(n=67)$ & $64.2(n=81)$ & $\chi_{2}^{2}=46.2, P<0.001$ \\
\hline Mean (SD) & $47.8 \pm 29.4$ & $62.5 \pm 14.8$ & & \\
\hline
\end{tabular}

${ }^{a}$ Intensive rat trapping took place around the study nests

b Oceanographic events lead to widespread adult mortality and breeding failures of seabirds nesting on West Falkland, including New Island (Huin 2003, own unpublished data)

Kerguelen group, where average success (fledging per nesting pairs) over 14 years was $51.9 \% \pm 9.0$ (SD); at this latter site, the only introduced mammal is the house mouse, which is not known to have any impact on the prions (Nevoux and Barbraud 2005, H. Weimerskirch, personal communication). On New Island, success was low only in the area with tussock grass stands. However, given that less than $2 \%$ of the local prions nest in tussock (calculated from data in Catry et al. 2003 and unpublished), we estimate that the overall breeding success of the colony is little affected by the low output in tussock.

The reasons for the low breeding success in tussock are unclear and need further investigation. However, it seems highly likely that rats are partly responsible. First, wounded chicks and signs of rodent predation (of both small and half-grown chicks) were found inside several nests. Second, prion remains were found inside rat stomachs. Third, on New Island, rodents are relatively more abundant in tussock stands than in other habitats (unpublished data). Fourth, when rats were controlled, breeding success improved; however, a more carefully designed experiment would be needed to confirm this (see Jouventin et al. 2003). Fifth, elsewhere in the Falkland Islands, thin-billed prions can nest in dense colonies in predator-free islands covered by tussock and hence must be adapted, under natural conditions, to reproduce successfully in those habitats. Other chick predators, such as skuas Catharacta antarctica and striated caracaras Phalcoboenus australis could not account for differences in breeding success because they seem to hunt less in tussock areas.

The reason why a small petrel, such as the thinbilled prion on New Island, manages to coexist with cats and rats probably lies in an inverse density-dependent type of interaction between terrestrial predators and petrel prey (see Cuthbert 2002 for an example).
Prions are extremely numerous on New Island, but only during the breeding season. On the other hand, rats and cats seem to be relatively scarce (unpublished data), probably due to the scarcity of winter food resources. Tussock, which in other subantarctic islands is an important source of food and shelter for rats (e.g. Pye et al. 1999), is very scarce on New Island. Furthermore, there are no winter-nesting seabirds on New Island that might provide a complementary source of food. In spring and summer, predators that survive the winter are apparently swamped by an over-abundance of potential prey. More research is needed to confirm these suggestions, but, at present, we have no other hypothesis, nor any evidence that contradicts these ideas.

This study suggests that introduced mammals do not currently have a significant impact on the reproduction of thin-billed prions on New Island. However, the low breeding success in tussock areas may illustrate what could happen if the relative numbers of prions and rodents changed. In an era of growing concerns and evidence for ecosystem changes, one must anticipate the scenario where external factors could lead to an increase in rodent populations, or to a decline in prion numbers, that would disrupt the apparent present equilibrium and potentially lead to the disappearance of prions from New Island. As such, further study of this system is required (including an assessment of predation pressure on adult birds) and long-term monitoring should constitute a major priority, at least until the resources are gathered and a successful eradication is eventually carried out.

Acknowledgments To Maria Strange and to Shona Strange for support in the field and in Stanley. This study was financed by Fundação para a Ciência e Tecnologia (FCT-Portugal) as part of the Programa Plurianual (UI\&D 331/94) and by research grants Praxis XXI BPD/11631/02 to PC and BD/9356/96 to MCS. 
Further support was received from the Foreign \& Commonwealth Office through an Overseas Territories Environment Programme (OTEP) grant (FAL 201) and from grants provided by Deutsche Forschungsgemeinschaft DFG, Germany (Qu 148/1). All work was approved by the Falkland Islands Government (Environmental Planning Office).

\section{References}

Brooke M (2004) Albatrosses and petrels across the world. Oxford University Press, Oxford

Catry P, Campos A, Segurado P, Silva M, Strange I (2003) Population census and nesting habitat selection of thin-billed prion Pachyptila belcheri on New Island, Falkland Islands. Polar Biol 26:202-207

Cuthbert R (2002) The roles of introduced mammals and inverse density-dependent predation in the conservation of Hutton's shearwater. Biol Conserv 108:69-78

Cuthbert R, Hilton G (2004) Introduced house mice Mus musculus: a significant predator of threatened and endemic birds on Gough Island, South Atlantic Ocean? Biol Conserv 117:483489

Huin N (2003) Falkland Island seabird monitoring programme, annual report 2002-2003. Falklands Conservation, Stanley

Jouventin P, Bried J, Micol T (2003) Insular bird populations can be saved from rats: a long-term experimental study of whitechinned petrels Procellaria aequinoctialis on Ile de la Possession (Crozet archipelago). Polar Biol 26:371-378
Martin J-L, Thibault J-C, Bretagnolle V (2000) Black rats, island characteristics and colonial nesting birds in the Mediterranean: consequences of an ancient introduction. Conserv Biol 14:1452-1466

Moors PJ, Atkinson IAE (1984) Predation on seabirds by introduced animals, and factors affecting its severity. In: Croxall JP, Evans PGH, Schreiber RW (eds) Status and conservation of the world's seabirds. International council for bird preservation, Technical Publication 2, Cambridge, pp 667-690

Nevoux M, Barbraud C (2005) Relationships between sea ice concentration, sea surface temperature and demographic traits of thin-billed prions. Polar Biol 29:445-453

Newton I (1998) Population limitation in birds. Academic, San Diego

Pye T, Swain R, Seppelt RD (1999) Distribution and habitat use of the feral black rat (Rattus rattus) on subantarctic Macquarie Island. J Zool 247:429-438

Quillfeldt P, Masello JF, Strange IJ (2003) Breeding biology of the thin-billed prion Pachyptila belcheri at New Island, Falkland Islands: egg desertion, breeding success and chick provisioning in the poor season 2002-2003. Polar Biol 26:746752

Quillfeldt P, Strange IJ, Masello JF (2006) Sea surface temperatures and behavioural buffering capacity in thin-billed prions: breeding success, provisioning and chick begging. J Avian Biol

Strange IJ (1980) The thin-billed prion Pachyptila belcheri, at New Island, Falkland Islands. Gerfaut 70:411-445 